\title{
PENAFSIRAN AYAT-AYAT AHKAM TENTANG WAKAF
}

Oleh :

\section{HAMDAN FIRMANSYAH ${ }^{1}$}

Email: abihilqi@gmail.com

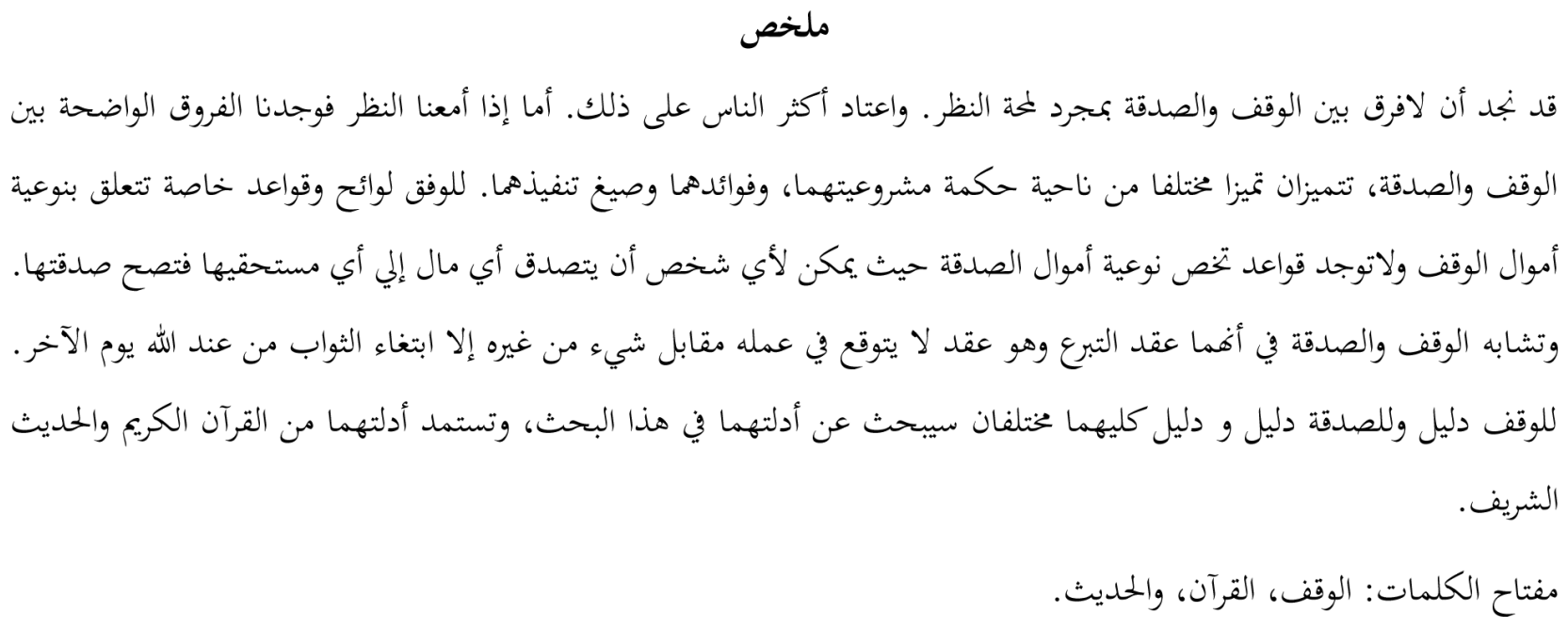

Abstract

When viewed at a glance, waqf and sedaqah are almost the same, this has even become commonplace in most ordinary people. However, if examined more deeply, it can be concluded the differences between waqf and sedeqah, which between them are very different, both in terms of wisdom, usability and how they are implemented. Among endowments and alms also have different wisdom. Endowments basically have special rules, especially on the type of assets that are represented. this is different from those who do not have specific regulations. As long as they have the property to disregard and there are people who will receive the money, then it has been legitimate to do so. Endowments and sedeqah also have similarities, namely the two actions are deeds that are classified into acts of tabarru' 'which are actions that do not expect anything in return from the recipient of waqf or sedeqah. Endowments and sedeqah also have different separate propositions which will be discussed later in this article, which are from the Quran and the Hadith of the Prophet.

Keywords: Waqf, Hadith, Al Quran.

\section{Abstrak}

Bila dilihat sepintas, wakaf dan sedaqah hampirlah sama, hal ini bahkan telah lumrah pada sebagian besar masyarakat yang awam. Namun apabila ditela'ah lebih mendalam maka dapat disimpulkan perbedaan-perbedaan antara wakaf dan sedeqah, yang diantara keduanya amat berlainan, baik dari segi hikmah, kegunaan dan cara pelaksanaannya. Diantara wakaf dan sedekah juga mempunyai hikmah tersendiri yang berbeda pula. Wakaf pada dasarnya memiliki peraturan-peraturan khusus, terutama pada jenis harta yang diwakafkan. hal ini berbeda dengan sedaqah yang tidak memiliki peraturan-peraturan yang khusus. Asalkan memiliki harta untuk disedaqahkan dan ada orang yang akan menerima sedeqah tersebut maka sedeqah telah sah untuk dilakukan. Wakaf dan sedeqah juga memiliki persamaan yaitu kedua perbuatan tersebut adalah perbuatan yang diklasifikasikan kepada perbuatan tabarru' yaitu perbuatan yang tidak mengharapkan balasan apa-apa dari si penerima wakaf atau sedeqah, tetapi

\footnotetext{
${ }^{1}$ Mahasiswa Program Doktor Hukum Islam Konsentrasi Hukum Ekonomi Syariah Universitas Islam Negeri Sunan Gunumg Djati Bandung.
} 
yang diharapkan dari wakaf dan sedeqah adalah balasan pahala dari Allah SWT dihari akhirat nanti. Wakaf dan sedeqah juga memiliki dalil-dalil tersendiri yang berbeda yang akan dibahas dalam tulisan ini nantinya, yang mana dalil-dalil tersebut berasal dari Al Quran dan Hadist Nabi.

Keyword: Wakaf, Hadist, Al Quran

\section{A. PENDAHULUAN}

Wakaf secara harfiah berarti berhenti, menahan atau diam. Wakaf sering kali diartikan sebagai aset yang dialokasikan untuk kemanfaatan umat di mana substansi ditahan, sementara manfaatnya boleh dinikmati untuk kepentingan umum. Secara administratif wakaf dikelola oleh nâzhir yang merupakan pengemban amanah wâqif (orang yang memberi wakaf). ${ }^{2}$

Dalam istilah wakaf adalah sejenis pemberian yang pelaksanaanya dilakukan dengan jalan menahan (kepemilikan) asal (tahbisul ashli), lalu menjadikan manfaatnya berlaku umum. Yang dimaksud tahbisul ashli ialah menahan barang yang diwakafkan agar tidak diwariskan, dijual, dihibahkan, digadaikan, disewakan dan sejenisnya. Sedangkan cara pemanfaatanya adalah menggunakan sesuai dengan kehendak pemberi wakaf tanpa imbalan. ${ }^{3}$

Wakaf merupakan salah satu bagian yang sangat penting dari hukum Islam. Ia mempunyai jalinan hubungan antara kehidupan spritual dengan bidang sosial ekonomi masyarakat muslim. Wakaf selain berdimensi 'ubudiyah ilahiyah, ia juga berfungsi sebagai sosial kemasyarakatan. Ibadah wakaf merupakan manisfestasi dari rasa keimanan seseorang yang mantap dan rasa solidaritas yang tinggi terhadap sesama umat manusia. Wakaf sebagai perekat hubungan "hablumminallah wa hablum minannas", hubungan vertikal kepada Allah dan hubungan horizontal kepada sesama manusia.

Wakaf merupakan salah satu ibadah kebendaan yang penting yang secara ekplisit tidak memiliki rujukan dalam kitab suci Al-Qur'an. Walaupun dalam al-Qur'an, kata wakaf yang bermakna memberikan harta tidak ditemukan sebagaimana zakat, tetapi ia merupakan interprestasi ulama mujtahid terhadap ayat-ayat yang membicarakan pendermaan harta berupa sedekah dan 'amal jariyah. Di antara ayat-ayat tersebut yaitu QS. Ali Imran/ 3: 92 dan QS. AlHajj/ 22: 77, para ulama memahami ayat-ayat tersebut sebagai ibadah wakaf. Meski demikian, al-Qur'an dapat dikatakan sebagai sumber utama perwakafan. Lalu bagaimana sebenarnya penafsiran terhadap ayat-ayat yang dijadikan sebagai dalil dianjurkannya wakaf tersebut.

Dalam tulisan ini akan dibahas pengertian dan hal-hal yang berkaitan dengan wakaf dan penafsiran ayat al-Qur'an yang dijadikan sebagai dalil dianjurkannya wakaf di atas.

\section{B. PEMBAHASAN}

a. Substansi Wakaf

\section{Pengertian Wakaf}

Menurut bahasa wakaf berasal dari waqf yang berarti radiah (terkembalikan), al-tahbis (tertahan), al-tasbil (tertawan) dan al-man'u (mencegah). ${ }^{4}$ Perkataan wakaf yang menjadi bahasa Indonesia, berasal dari bahsa Arab dalam bentuk masdar atau kata yang dijadikan kata kerja atau fi'il waqafa. Kata kerja atau fi'il waqafa ini adakalanya memerlukan objek (muta'addi). Dalam perpustakaan sering ditemui sinonim waqf ialah habs. Waqafa dan habasa dalam bentuk kata kerja yang bermakna menghentikan dan menahan atau berhenti di tempat. ${ }^{5}$

Sedangkan menurut istilah syara, ialah menahan sesuatu benda yang kekal zatnya, untuk diambil manfaatnya untuk kebaikan dan kemajuan Islam. Menahan suatu benda yang kekal zatnya,

\footnotetext{
${ }^{2}$ Achmad Djunaidi, Menuju Era Wakaf Produktif (Depok: Mumtaz Publishing, 2007), III.

${ }^{3}$ Departemen Agama RI, Paradigma Baru Wakaf di Indonesia (t.t: Paradigma Baru, 2007), 1

${ }^{4}$ Muhammad al-Syarbini al-Khatib, Al-'Iqna fi Hall al-Alfadz Abi Syuza, (Dar al-Ihya al-Kutub: Indonesia, t.t), 319

${ }^{5}$ Abdul Halim, Hukum Perwakafan di Indonesia, cet.I. (Ciputat: Ciputat Press, 2005), 6
} 
artinya tidak dijual dan tidak diberikan serta tidak pula diwariskan, tetapi hanya disedekahkan untuk diambil manfaatnya saja.

Ada beberapa pengertian tentang wakaf antara lain:

1. Menurut mazhab syafi'i dan hambali adalah seseorang menahan hartanya untuk bisa dimanfaatkan di segala bidang kemaslahatan dengan tetap melanggengkan harta tersebut sebagai taqarrub kepada Allah SWT.

2. Menurut imam Abu Hanafi adalah menahan harta-benda atas kepemilikan orang yang berwakaf dan bershadaqah dari hasilnya atau menyalurkan manfaat dari harta tersebut kepada orang-orang yang dicintainya. Berdasarkan definisi dari Abu Hanifah ini, maka harta tersebut ada dalam pengawasan orang yang berwakaf (wakif) selama ia masih hidup, dan bisa diwariskan kepada ahli warisnya jika ia sudah meninggal baik untuk dijual atau dihibahkan.

3. Menurut mazhab Maliki adalah memberikan sesuatu hasil manfaat dari harta, dimana harta pokoknya tetap/lestari atas kepemilikan pemberi manfaat tersebut walaupun sesaat.

4. Menurut Peraturan Pemerintah/ PP No.41 tahun 2004 adalah perbuatan hukum wakif untuk memisahkan sebagian benda miliknya, untuk dimanfaatkan selamanya atau dalam jangka waktu tertentu sesuai kepentingannya guna keperluan ibadah atau kesejahteraan umum menurut syariah

Dari definisi tersebut dapat diambil kesimpulan bahwa wakaf itu termasuk salah satu diantara macam pemberian, akan tetapi hanya boleh diambil manfaatnya, dan bendanya harus tetap utuh. Oleh karena itu, harta yang layak untuk diwakafkan adalah harta yang tidak habis dipakai dan umumnya tidak dapat dipindahkan, misalnya tanah, bangunan dan sejenisnya. Utamanya untuk kepentingan umum, misalnya untuk masjid, mushala, pondok pesantren, panti asuhan, jalan umum, dan sebagainya.

\section{Rukun Wakaf}

1. Wâqif (orang yang mewakafkan harta)

2. Mauqûf bîh (barang atau harta yang diwakafkan)

3. Mauqûf 'alaih (pihak yang diberi wakaf/ peruntukkan wakaf)

4. Shîghat (pernyataan atau ikrar wakif sebagai suatu kehendak untuk mewakafkan sebagian harta bendanya). ${ }^{6}$

\section{Syarat-Syarat Wakaf}

1. Selama-lamanya (tidak dibatasi dengan waktu)

2. Tunai dan tidak ada khiyar syarat

3. Hendaklah jelas kepada siapa diwakafkan. ${ }^{7}$

b. Ayat Ahkam dan Penafsiran Tentang Wakaf 1. Surat Ali Imran Ayat 92:

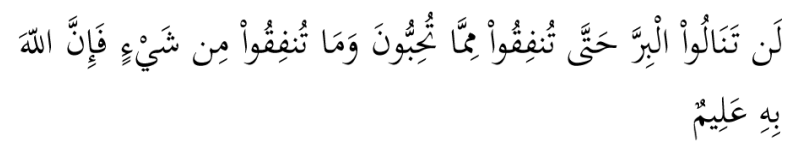

Artinya: Kamu tidak akan memperoleh kebajikan, sebelum kamu menginfakkan sebagian harta yang kamu cintai. Dan apa pun yang kamu infakkan, tentang hal itu sungguh, Allah Maha Mengetahui. ${ }^{8}$

\section{Tafsir Surat Ali Imran Ayat 92}

Dalam ayat ini menegaskan bahwa tidak akan meraih kebaikan sebelum kalian menginfakkan sebagian harta yang kalian cintai. ${ }^{9}$ Dan apa saja yang kalian infakkan, maka sesungguhnya Allah pasti megetahuinya. Anjuran untuk bernafkah di jalan Allah SWT, apa yang disukai. Mencampurkan yang disukai atau yang tidak disukai pun dapat ditoleransi, tetapi itu bukan cara terbaik untuk meraih kebajikan yang sempurna. ${ }^{10}$

\footnotetext{
${ }^{6}$ Departemen Agama RI, Fiqih wakaf (t.t: Paradigma Baru, 2007), 21.

${ }^{7}$ Sulaiman Rasjid, Fiqih Islam (Bandung: Sinar Baru Algensindo, 2014), 341-343

${ }^{8}$ QS: Ali Imran: 92

${ }^{9}$ M. Quraisy Shihab, al-Lubab: Makna, Tujuan, dan Pembelajaran dari Surah-Surah al-Qur'an, (Tangerang: Lantera Hati, 2012 ), 121

${ }^{10}$ M. Quraisy Shihab, al-Lubab: Makna, Tujuan, dan Pembelajaran dari Surah-Surah al-Qur'an, 122.
} 
Kemudian makna lan tanâlul birra (sekalikali kalian tidak akan meraih kebaikan), yakni segala yang ada di sisi Allah SWT. berupa pahala, kemuliaan, dan surga hanya dapat diraih manakala kalian menginfakkan harta yang kalian cintai. Menurut pendapat yang lain, lan tanâlul birra berarti, kalian tidak akan sampai pada ketawakalan dan ketakwaan. Hattâ tunfiqû min mâ tuhibbûn, wa mâ tưfiqû min syai in (sebelum kalian menginfakkan sebagian harta yang kalian cintai. Dan apa saja yang kalian infakkan), yakni harta benda. Fa innallâha bihî (maka sesungguhnya Allah kepadanya) dan kepada niat kalian.'Alîm (pasti mengetahui), apakah bertujuan untuk mengharap ridha Allah SWT. atau demi mendapat pujian orang lain. ${ }^{11}$ Kata al-Birr di atas, pada mulanya berarti "keluasan dalam kebajikan" dan dari akar kata yang sama dengan kata "daratan" dinamai al-barr karena luasnya kebajikan mencakup segala bidang, serta tentu saja termasuk menginfakkan harta di jalan Allah (be rwakaf). ${ }^{12}$

Pada ayat sebelumnya disebutkan bahwa siapa yang meninggal dalam kekufuran maka tidak akan diterima atau berguna nafkahnya untuk menampik siksa yang akan menimpanya. Maka disini dikemukakan kapan dan bagaimana sehingga nafkah seseorang dapat bermanfaat. Yakni bahwa yang dinafkahkan hendaknya harta yang disukai, karena kamu sekali-kali tidak meraih kebajikan (yang sempurna), sebelum kamu menafkahkan sebahagian dari harta benda yang kamu sukai dengan cara yang baik dan tujuan yang baik serta motivasi yang benar. Jangan khawatir untuk rugi atau menyesal dengan pemberianmu yang tulus, karena apa yang kamu nafkahkan baik itu dari harta yang kamu sukai maupun yang tidak kamu sukai. Maka sesungguhnya tentang segala sesuatu yang menyangkut hal itu Allah Maha Mengetahui, dan Dia yang akan memberi ganjaran untuk kamu, baik itu di dunia maupun di akhirat kelak.
Thabathaba'i ${ }^{13}$ dalam tafsirnya, alMizan, menyebutkan seteleh terlebih dahulu mengemuka-kan ketidakjelasan hubungan ayat ini dengan ayat-ayat sebelumnya. Ia menduga boleh jadi ayat ini ditujkan kepada Bani Isra'il. Yakni setelah dalam ayat-ayat yang lalu mereka dikecam akibat perhatian dan kecintaan yang demikian besar terhadap kehidupan dunia dan harta dengan mengabaikan tuntunan agama, di sini mereka sekali lagi dikecam bahwa "kalian berbohong ketika berkata bahwa kalian adalah kekasih Allah dan pengikut para Nabi. Atau orang-orang yang bertakwa dan berbuat kebaikan, karena kalian sangat mencintai harta-harta kalian yang baik dan kikir menafkahkannya, padahal kalian tidak akan meraih kesempurnaan dalam kebajikan jika tidak menafkahkan apa yang kalian sukai".

\section{Surat Al-Hajj Ayat 77:}

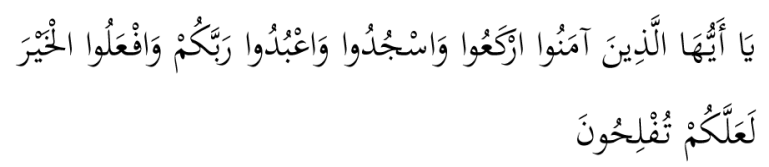

Artinya: Wahai orang-orang yang beriman! Rukuklah, sujudlah dan sembahlah Tuhanmu; dan berbuatlah kebaikan, agar kamu beruntung. ${ }^{14}$

\section{Tafsir Surat Al-Hajj Ayat 77}

Maksud kata "Waf'alû al-Khair" (kerjakanlah kebaikan) yaitu mengerjakan kebaikan mencakup setiap apa saja yang bisa memperindah hubungan hamba dengan Tuhannya, dan memperbagus hubungan hamba dengan sesama manusia. Perintah di sini lebih umum, yakni melakukan setiap kebajikan yang mencakup ibadah, ketika kita memperhatikan makna ayat ini akan menemukan bahwa perintah dalam ayat tersebut masih runtut. Pertama ayat tersebut memerintahkan ibadah khusus yaitu shalat, kemudian memerintahkan melakukan ibadah umum yaitu semua ibadah, "sembahlah tuhan kalian”, memerintahkan dengan perintah yang

\footnotetext{
${ }^{11}$ Ali bin Abi Thalhah, Tanwîrul Miqbâs min Tafsir Ibnu 'Abbas (Beirut: Dar al-Kutub al-Ilmiyah, 1991)

${ }_{12}^{12}$ M. Quraisy Shihab, Tafsir al-Misbah: Pesan, Kesan an Keserasian al-Qur'an, juz 2 (Ciputat, Lentera Hati, 2000), 142-143

${ }^{13}$ Nama lengkapnya adalah Muhammad Husein Thabathaba'i. ia adalah seorang mufassir, syekh di bidang syariat Islam dan ilmu esoteris, hakim, filsuf, dan ulama-pemikir modernis yang lahir di Tabris Iran tahun 1903 dan wafat pada tahun 1981

${ }^{14}$ QS. Al-Hajj: 77
} 
lebih umum dari kesemuanya, dalam firman Allah "lakukanlah kebajikan".

Pendapat lain dikatakan, bahwa perintah melakukan ibadah mencakup mengerjakan yang fardhu, sedangkan perintah melakukan kebajikan adalah mencakup ibadah sunnah."La'allakum Tuflihûn" (mudah-mudahan kalian termasuk orang yang beruntung). Kata mudah-mudahan adalah sebuah harapan yang hakiki, yaitu mentakdirkan bahwa ini harapan dari seorang hamba. Beruntung adalah keuntungan memperoleh laba, yaitu kebahagian abadi di hari akhir dan kesejukan hidup di dunia. ${ }^{15}$

Sedangkan di dalam tafsir al-Mishbah, kata La'allakum tuflihun (semoga kamu mendapat kemenangan) mengandung isyarat bahwa amal-amal yang diperintahkan itu, hendaklah dilakukan dengan harapan memperoleh al-falah (keberuntungan) yakni apa yang diharapkan di dunia dan di akhirat. Kata la'alla (semoga) yang tertuju kepada para pelaksana kebaikan itu, memberi kesan bahwa bukan amal-amal kebaikan itu yang menjamin perolehan harapan dan keberuntungan apalagi surga, tetapi surga adalah anugerah Allah dan semua keberuntungan merupakan anugerah dan atas izin-Nya semata.

Kata tuflihun terambil dari kata falaha yang juga digunakan dalam arti bertani. Penggunaan kata itu memberi kesan bahwa seorang yang melakukan kebaikan, hendaknya jangan segera mengharapkan tibanya hasil dalam waktu yang singkat. Ia harus merasakan dirinya sebagai petani yang harus bersusah payah membajak tanah, menanam benih, menyingkirkan hama, dan menyirami tanamannya, lalu harus menunggu hingga memetik buahnya. ${ }^{16}$

M. Quraish Shihab berpendapat bahwa ayat ini secara umum telah mencakup semua tuntunan Islam, dimulai dari akidah yang ditandai dengan penamaan mereka yang diseru dengan sebutan “orang-orang yang beriman”, selanjutnya dengan memerintahkan shalat dengan menyebut dua rukunnya yang paling menonjol yaitu rukuk dan sujud. Perintah shalat disebutkan secara khusus karena ibadah ini merupakan tiang agama. Setelah itu disebut aneka ibadah yang mencakup banyak hal, bahkan dapat mencakup aktivitas seharihari jika motivasinya adalah mencari ridha ilahi, dan akhirnya ditutup dengan perintah berbuat kebajikan yang menampung seluruh kebaikan duniawi dan ukhrawi, baik yang berdasar wahyu maupun nilai-nilai yang sejalan dengan tujuan syariat, baik yang berupa hukum dan undangundang maupun tradisi dan adat istiadat. Jika halhal di atas dipenuhi oleh satu masyarakat, maka tidak diragukan pastilah mereka secara individual dan kolektif, akan meraih keberuntungan yakni meraih apa yang mereka harapkan di dunia dan di akhirat. ${ }^{17}$

Al-Maraghi menafsirkan ayat ini sebagai berikut: "Wahai orang-orang yang mempercayai Allah dan rasul-Nya, tunduklah kepada Allah dengan bersujud, beribadahlah kepada-Nya dengan segala apa yang kalian gunakan untuk menghambakan diri kepada-Nya, dan berbuatlah kebaikan yang diperintahkan kepada kalian, seperti mengadakan hubungan silaturahmi dan menghiasi diri dengan akhlak yang mulia, supaya kalian beruntung memperoleh pahala dan keridhaan yang kalian cita-citakan." 18

Ayat di atas, memang tidak secara tegas menyinggung tentang wakaf. Namun, ayat di atas lah yang dijadikan para ahli fiqih sebagai dalil dianjurkannya berwakaf didasarkan pada keumuman ayat-ayat al-Quran tentang perintah lakukanlah kebaikan, yang mana kata kebaikan itu mengandung arti yang umum yang termasuk pula di dalamnya perintah untuk berwakaf, karena dengan wakaf akan mendekatkan hubungan seorang hamba dengan tuhannya dan dengan sesama manusia.

\footnotetext{
${ }^{15}$ Ahmad Muhammad al-Hushari, Tafsir ayat-ayat ahkâm terj. Abdurrahman Kasdi (Jakarta: Pustaka al-Kautsar), 65.

${ }^{16}$ M. Quraisy Shihab, Tafsir al-Misbah: Pesan, Kesan an Keserasian al-Qur'an, 132-133

${ }^{17}$ M. Quraisy Shihab, Tafsir al-Misbah: Pesan, Kesan an Keserasian al-Qur'an, 132-133

${ }^{18}$ Ahmad Mushthafa Al-Maraghi, Tafsir al-Maraghi (Kairo: Mushthafa al-Babi al-Halabi, 1993), 262
} 
Ulama berpendapat bahwa perintah wakaf merupakan bagian dari perintah untuk melakukan al-khayr (secara harfiah berarti kebaikan). Imam Al-Baghawi menafsirkan bahwa peerintah untuk melakukan al-khayr berarti perintah untuk melakukan silaturrahmi, dan berakhlak yang baik. Sementara Taqiy al-Din Abi Bakr Ibn Muhammad al-Husaini al-Dimasqi menafsirkan bahwa perintah untuk melakukan al-khayr berarti perintah untuk melakukan wakaf.

Dalam ayat tentang wasiat, kata al-khayr diartikan dengan harta benda. Oleh karena itu, perintah melakukan al-khayr berarti perintah untuk melakukan ibadah bendawi. Dengan demikian, wakaf sebagai konsep ibadah kebendaan berakar pada al-khayr. Allah memerintahkan manusia untuk mengerjakannya.

Bertitik tolak dari ayat al-Quran yang menyinggung tentang wakaf tersebut nampak tidak terlalu tegas. Karena itu sedikit sekali hukumhukum wakaf yang diterapkan berdasarkan kedua sumber tersebut. Sehingga ajaran wakaf ini diletakan pada wilayah yang bersifat ijtihadi, bukan ta'abbudi, khususnya yang berkaitan dengan aspek pengelolaan, jenis wakaf, syarat, peruntukan dan lain-lain.

Meskipun demikian, ayat al-Quran yang sedikit itu mampu menjadi pedoman para ahli fiqih Islam. Sejak masa Khulafa ur Rasyidin sampai sekarang, dalam membahas dan mengembangkan hukum-hukum wakaf dengan menggunakan metode penggalian hukum (ijtihad) mereka. Sebab itu sebagian besar hukum-hukum wakaf dalam Islam ditetapkan sebagai hasil ijtihad, dengan menggunakan metode ijtihad seperti qiyas, mashlahah mursalah dan lain-lain.

\section{c. Penjelasan Hadits Ahkam Tentang Wakaf}

Adapun Hadis yang menjadi dasar dari wakaf yaitu Hadis yang menceritakan tentang kisah Umar bin al-Khaththab ketika menerima tanah di Khaibar.

\footnotetext{
${ }^{19}$ HR Bukhari no. 2532 dan Muslim no. 3085

${ }^{20}$ Lihat: Sunan Tirmidzi 5/13 setelah hadits No. 1375
}

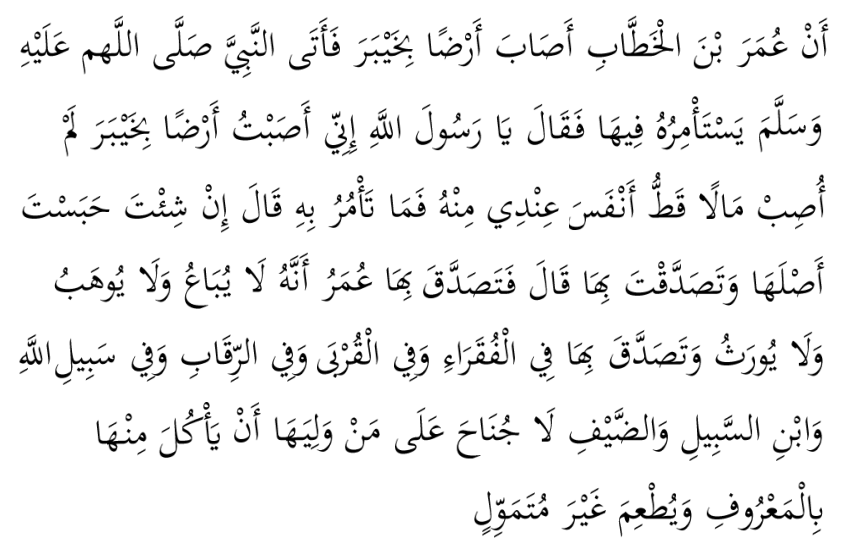

Artinya: "Bahwa 'Umar ibnul Khaththab menghadapi masalah tanah di Khaibar lalu menghadap kepada Nabi Saw mempertanyakan hal itu katanya: "Ya Rasulullah aku mendapatkan tanah di Khaibar tidak ada harta lain yang lebih berharga dari tanah itu, maka apa yang harus aku kerjakan? Beliau bersabda: "Jika kalian suka tahanlah tanahnya lalu sedekahkan hasilnya" Kemudian "Umar menyedekahkan hasilnya, tanah itu tidak dijual, tidak dihibahkan, tidak diwariskan, tetapi hasilnya disedekahkan kepada para fakir miskin, kerabat dekat, budak, Sabilillah, Ibnu Sabil dan tamu. Tidak mengapalah orang yang mengelolanya untuk makan mengambil hasil dari tanah itu secara baik-baik, memberi makan tanpa ingin memilikinya." 19

Imam Tirmidzi menyatakan: Wakaf telah diamalkan oleh para ulama, baik dari kalangan sahabat Nabi maupun yang lainnya, saya tidak melihat ada perbedaan pendapat di kalangan ulama mutaqaddimin tentang bolehnya wakaf, baik wakaf tanah maupun wakaf yang lainnya. ${ }^{20}$ Imam AlBaghawy berkata: Wakaf telah diamalkan oleh seluruh ulama, baik dari generasi sahabat, maupun orang setelah mereka, seperti ulama mutaqaddimin; mereka tidak berselisih pandangan tentang bolehnya wakaf tanah maupun wakaf harta-barang bergerak; para sahabat Muhajirin dan Anshar melakukan wakaf, baik di Madinah maupun di daerah lainnya; tidak ada riwayat satupun dari mereka yang mengingkari adanya syariat wakaf; bahkan tidak pernah ada 
dari mereka yang mencabut kembali wakafnya dengan alasan dirinya masih membutuhkannya. ${ }^{21}$ Imam Ibn Hazm berkata: Seluruh sahabat Nabi, shadaqahshadaqah mereka di kota Madinah lebih masyhur/ terkenal daripada matahari, tidak ada seorang pun yang tidak mengetahuinya. ${ }^{22}$

Hukum wakaf sama dengan amal jariyah. Sesuai dengan jenis amalnya maka berwakaf bukan sekedar berderma (sedekah) biasa, tetapi lebih besar pahala dan manfaatnya terhadap orang yang berwakaf. Pahala yang diterima mengalir terus menerus selama barang atau benda yang diwakafkan itu masih berguna dan bermanfaat. Hukum wakaf adalah sunah. Ditegaskan dalam hadits. $^{23}$

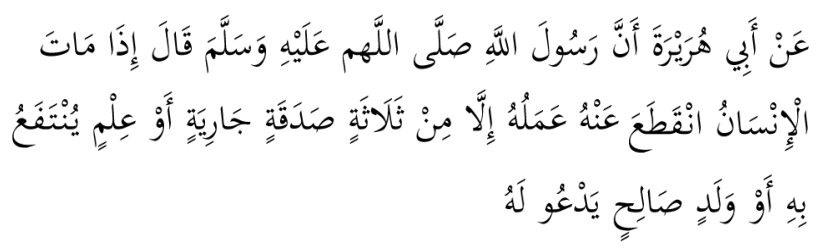

Artinya: "Dari Abu Hurairah bahwa Rasulullah Saw bersabda: "Orang meninggal itu terputus amalnya kecuali 3 amal, yaitu: Sedekah Jariyah, ilmu yang bermanfaat dan anak yang soleh yang mendo'akannya"24

Harta yang diwakafkan tidak boleh dijual, dihibahkan atau diwariskan. Akan tetapi, harta wakaf tersebut harus secara terus menerus dapat dimanfaatkan untuk kepentingan umum sebagaimana maksud orang yang mewakafkan. Hadits Nabi yang artinya: "Sesungguhnya Umar telah mendapatkan sebidang tanah di Khaibar. Umar bertanya kepada Rasulullah SAW; Wahai Rasulullah apakah perintahmukepadakusehubungandengan tanah tersebut? Beliau menjawab: Jika engkau suka tahanlah tanah itu dan sedekahkan manfaatnya! Maka dengan petunjuk beliau itu, Umar menyedekahkan tanahnya dengan perjanjian tidak akan dijual tanahnya, tidak dihibahkan dan tidak pula diwariskan." 25

\section{d. Hikmah dan Manfaat Wakaf Dalam Kehidupan}

Manfaat wakaf dalam kehidupan dapat dilihat dari segi hikmahnya. Setiap peraturan yang disyariatkan Allah SWT kepada makhluknya baik berupa perintah atau larangan pasti mempunyai hikmah dan ada manfaatnya bagi kehidupan manusia, khususnya bagi umat Islam. Manfaat itu bisa dirasakan ketika hidup sekarang maupun setelah di akhirat nantinya yaitu berupa pahala (didasarkan pada janji Allah). Ibadah wakaf yang tergolong pada perbuatan sunnat ini banyak sekali hikmahnya yang terkandung di dalam wakaf ini.

Pertama, harta benda yang diwakafkan dapat tetap terpelihara dan terjamin kelangsungannya. Tidak perlu khawatir barangnya hilang atau piindah tangan, karena secara prinsip barang wakaf tidak boleh ditassarrufkan, apakah itu dalam bentuk menjual, dihibahkan, atau diwariskan. Kedua, pahala dan keuntungan bagi si wakif akan tetap mengalir walaupun suatu ketika ia telah meninggal dunia, selagi benda wakaf itu masih ada dan dapat dimanfaatkan. Ketiga, wakaf merupakan salah satu sumber dana yang sangat penting manfaatnya bagi kehidupan agama dan umat. Antara lain untuk pembinaan mental spritual dana pembangunan dari segi fisik.

Wakaf disamping mempunyai nilai ibadah, sebagai tanda syukur seorang hamba atas nikmat yang telah di anugerahkan Allah SWT, juga berfungsi sosial. Dengan wakaf, di samping dana-dana sosial lainnya, kepincangan di antara kelompok yang tidak berada dapat dipertipis atau jurang antara si miskin dan si kaya dapat di hilangkan terutama dalam bentuk wakaf yang dikhususkan kepada kelompok yang tidak mampu. Dengan wakaf itu juga, penyediaan sarana dan prasarana ibadah, pendidikan, seperti mesjid, mushalla dan gedung-gedung pendidikan

\footnotetext{
${ }^{21}$ Lihat: Syarh Al-Sunnah 8/288

${ }^{22}$ Lihat: Al-Muhalla 9/180

${ }^{23}$ Hendi Suhendi, Fiqh Muamalah, (Jakarta: PT. Raja Grafindo Persada, 2010), 240

${ }^{24}$ HR Muslim No. 3084

${ }^{25}$ HR Bukhari dan Muslim
} 
akan lebih memugkinkan dengan menggunakan potensi wakaf yang ada.

Hikmah wakaf kata Ahmad Jarjawi, dapat membantu pihak yang miskin, baik miskin dalam artian ekonomi maupun tenaga. Silain pihak juga bertujuan unutk meningkatkan pembangunan keagamaan. Di samping itu hikmah lain adalah dapat membentuk jiwa sosial di tengah-tengah masyarakat. Dapat juga mendidik manusia agar mempunyai tenggang rasa terhadap sesamanya.

Dampak positif langsung dari ibadah wakaf itu akan membentuk tali hubungan yang errat antara wakif dan maukuf 'alaih atau anatara si kaya dan si miskin sehingga terciptalah rasa kesetiakawanan sosial. Melalui ibadah wakaf dua belah pihak memperoleh manfaatnya, baik bagi wakif (orang yang berwakaf) maupun bagi si maukuf'alaih (orang yang menerima wakaf). Bagi wakif dari segi agama mendapat pahala sedangkan maukufalaih terlepas dari kesulitan. Bahkan mampu menjadi sumber dana umat Islam untuk mengembangkan dakwah Islamiyah, tentu dengan mendayagunakan harta wakaf secara optimal.

Dengan demikian dapat diketahui bila wakaf itu dijalankan atau dilakukan menurut semestinya akan meningkatkan rasa sosial di tengah-tengah masyarakat sehingga terbentuklah atau terjalinlah hubungan yang harmonis antara si kaya dengan si miskin. Begitu juga sebaliknya dengan si miskin akan timbul rasa syukur kepada Allah SWT yang telah memberikan rezeki kepadanya, disamping itu akan timbul rasa hormat kepada si kaya yang telah menolongnya. Akhirnya timbul sinar keimanan bagi setiap individu dan terhindarlah dari segala perpecahan dan perselisihan di antara anggota masyarakat. Memang inilah yang di harapkan dan menjadi sasaran dari ajaran agama Islam.

\section{PENUTUP}

Berwakaf bukan hanya seperti sedekah biasa, tetapi lebih besar ganjarannya dan manfaatnya terhadap diri sendiri, karena ganjaran wakaf itu terus-menerus mengalir selama barang itu masih berguna, barang asalnya tetap, tidak boleh dijual, diwariskan, diberikan atau dihibahkan. Sekarang kalau kiranya wakaf itu tidak ada manfaatnya atau kurang manfaatnya maka boleh dijual. Seperti menjual tikar mesjid yang sudah tidak pantas dipakai lagi agar jangan tersia-sia maka hasilnya digunakan untuk kemaslahatan mesjid. Kata Ibnu Taimiyah, "sesungguhnya yang menjadi pokok disini guna menjaga kemaslahatan. Allah memerintahkan menjalankan kemaslahatan dan menjauhkan kerusakan. Allah mengutus utusanNya guna meneympurnakan kemaslahatan dan melenyapkan segala kerusakan.

Beberapa hal keutamaan wakaf, sebagai berikut : Melalui wakaf seseorang dapat menumbuhkan sifat zuhud dan melatih seseorang untuk saling membantu atas kepentingan orang lain. Dapat menghidupkan lembaga-lembaga sosial keagamaan maupun kemasyarakatan untuk mengembangkan potensi umat. Menanamkan kesadaran bahwa di dalam setiap harta benda itu meski telah menjadi milik seseorang yang secara sah, tetapi masih ada di dalamnya harta agama yang mesti diserahakan sebagaimana halnya zakat. Menyadarkan seseorang bahwa kehidupan di akhirat memerlukan persiapan yang cukup. Maka persiapan itu di antaranya wakaf, sebagai tabung akhirat. Keutamaan lain, dapat penopang dan penggerak kehidupan sosial kemasyarakatan umat Islam, baik aspek ekonomi, pendidikan, sosial budaya dan lainnya.

\section{Daftar Pustaka}

\section{Al-Quran Al-Karim}

Abdullah Bin Muhammad. Tafsir Ibnu Katsir. Jilid I. Bogor: Pustaka Imam Syafi'i

Abi Thalhah, Ali bin, 1991. Tanwîrul Miqbâs min Tafsir Ibnu 'Abbas. Beirut: Dar al-Kutub alIlmiyah

Al-Hushari, Ahmad Muhammad, Tafsir ayat-ayat ahkâm terj. Abdurrahman Kasdi. Jakarta: Pustaka al-Kautsar

Al-Khatib, Muhammad al-Syarbini, Al'Iqna fi Hall al-Alfadz Abi Syuza, (Indonesia : Dar al-Ihya al-Kutub , t.t) 
Al-Maraghi, Ahmad Mushthafa, 1993. Tafsir alMaraghi Kairo: Mushthafa al-Babi al-Halabi

Al-Mahali, Imam Jalaluddin. Al-Suyuti, Imam Jalaluddin. Tafsir Jalalain. Juz I, Bandung : Sinar Baru Algesindo

Al-Musyaiqih, Khalid ibn Ali ibn Muhammad, AlAuqaf fii Al-Ashr Al-Hadits, Kaifa Nuwajihuha lidda'mil Jami'at wa tanmiati mawaridiha

Ath-Thayar, Abdullah bin Muhammad, dkk. 2009. Ensiklopedi Fiqih Muamalah, terj. Miftahul Khair. Cet. 1; Yogyakarta: Maktabah alHanif.

Az-Zuhaili, Wahbah. 2011. Fiqih Islam Wa Adilatuhu: Penerjemah, Abdul Hayyie alKattani, dkk. Jakarta: Gema Insani Press.

Damas, Taufik, dkk. 2014. Al-Qur'an Tafsir Per Kata Al-Ahkam. Jakarta Timur: PT. Suara Agung Jakarta.

Departemen Agama RI, 2007. Paradigma Baru Wakaf di Indonesia (t.t: Paradigma Baru)
Departemen Agama RI, 2007. Fiqih Wakaf (t.t: Paradigma Baru)

Djunaidi, Achmad, 2007. Menuju Era Wakaf Produktif. Depok: Mumtaz Publishing

Halim, Abdul, 2005. Hukum Perwakafan di Indonesia. Ciputat: Ciputat Press

Hendi Suhendi, 2010. Figh Muamalah. Jakarta: PT. Raja Grafindo Persada

Rasyid, Sulaiman,. 2010. Fiqh Muamalah. Bandung: Sinar Baru Al-Gensindo 2014. Fiqih Islam. Bandung: Sinar Baru Algensindo

Shihab, M. Quraisy, 2012. al-Lubab: Makna, Tujuan, dan Pembelajaran dari Surah-Surah alQur'an. Tangerang: Lantera Hati

,Quraisy,2000. Tafsir al-Misbah: Pesan, Kesan an Keserasian al-Qur'an, juz 2. Ciputat, Lentera Hati. 